Cattle breeding

\section{Techniques for sexing embryos now possible}

\section{Washington}

CATTLE breeding for dairy and beef production could be revolutionized by a process for identifying the sex of 6-day-old calf embryos announced by Genetic Engineering Inc. of Denver, Colorado.

The company had announced the first successful use of its sex-identification process, when two female calves "Alpha" and "Beta", whose gender has been identified when they were embryos, were born naturally in December. Several more calves identified as females are due to be born in January and February. The company has begun identifying embryos and freezing them for shipment to customers.

Cattle are bred selectively for either dairy or beef. Females are needed almost exclusively for dairy herds, males almost exclusively for beef herds because they grow faster and have more meat.

Today, US cattle farmers routinely remove week-old embryos from their breeding animals so that they can conceive as often as possible. The embryos are then implanted non-surgically in surrogate mothers, which give birth naturally nine months later. Hitherto, the sex of a calf fetus could not be known until birth, so breeders had to feed the surrogate for nine months before knowing whether her offspring would be, in the case of dairy cattle, female and worth $\$ 2,500$ or male and worth $\$ 50$ as veal meat. Genetic

\section{Male determinant}

THE HY antigen used in Genetic Engineering's sexing test is a male determinant produced by the genes of the histocompatibility complex. Attempts to produce specific antibodies against the antigen have, however, mostly been frustrated. The British company International Embryos Limited (which says that its agreement with Genetic Engineering gives it the right to market sexed frozen embryos more widely than in South Africa) says it has been told that the sexing technique is 93 per cent accurate, suggesting good laboratory evidence that the monoclonal antibody developed by Wagner and Hoppe has high specificity.

The economics of the technique will, however, be determined not merely by the accuracy of the technique but also by the unknown degree to which embryos are damaged, or found unusable, in the laboratory. Cows used as a source of embryos are usually superovulated in advance, and their commercial value as sources of breeding material is determined by the number of viable embryos produced at each ovulation and insemination.
Engineering's sex-identification process would enable embryos only of the desired sex to be implanted in surrogates.

Genetic Engineering has filed a patent application for the new process, which Charles Srebnik, chairman of the company's board, would only describe as using monoclonal HY antibody and not removing any cells from the week-old embryo. The process was developed by Thomas E. Wagner of Ohio University, who is the chairman of the company's scientific advisory board and a stockholder in the company. The work was done at the company's laboratory in Denver, although the company does fund about $\$ 200,000$ worth of research at Ohio University Medical School.

The company expects an overseas market for its sex-typed embryos, especially in the Soviet Union, China and the Third World. Dairy cattle in developing countries produce 3,000 pounds of milk per year - whereas the selectively bred US dairy cow produces 16,000 pounds of milk a year. The intention is to sell frozen embryos abroad where they can be implanted in surrogate mothers of other breeds of cattle. The surrogate would then transfer her immunities to the fetus, enhancing its chances of adapting to the local environment after it is born.

The company has three joint venture arrangements: with Tower Tech International to sell embryos to Eastern Bloc countries, with the British company International Embryos Ltd to market in South Africa and with an Italian company for marketing in Italy and North Africa.

Despite its name, the company primarily does standard embryo transfer work for cattle breeders. In 1980, however, its name helped the company to raise $\$ 400,000$ through a limited offering and, in January 1981 , to net $\$ 3.3$ million through a public stock offering of shares selling for $\$ 5$. For most of 1982 the stock hovered at between $\$ 31 / 2$ and $\$ 41 / 2$ per share, but after the announcement of the new sexidentification process, the share price rose, closing at $\$ 6 \%$ on 31 December.

Company-sponsored research, however, include does gene-splicing. The work on the bovine growth hormone by Wagner at Ohio and Peter Hoppe at Jackson Laboratory, published in 1981, was sponsored under standard arrangements in which the company has first rights to any patentable product or process. Genetic Engineering had filed a patent for the bovine growth hormone process before Wagner and Hoppe published it.

Deborah Shapley
Research fraud

\section{False data confessed}

\section{Washington}

A FORMER researcher at Mt Sinai Medical School in New York City has admitted fabricating data that appeared in two scientific papers, a patent application that was granted, and a National Institute of Health (NIH) grant application and progress report.

The researcher, Dr Joseph Cort, was a part-time faculty member at Mt Sinai from 1976 to 1980 . His research involved the synthesis of analogues of vasopressin and luteinizing hormone releasing hormone (LHRH).

Dr Cort's admission was made public late last month after Mt Sinai officials completed a 10-month investigation that began when Vega Biochemicals of Tucson, at the time Dr Cort's employer, informed Mt Sinai that Dr Cort had admitted fabricating some of his research. Cort subsequently admitted to a Mt Sinai factfinding committee that he had not in fact synthesized one of five vasopressin analogues on which he reported results while at Mt Sinai. In examining laboratory records, the committee was unable to find evidence that a second vasopressin analogue had been synthesized either.

Laboratory records also showed discrepancies in a patent Cort received for the vasopressin analogues. Vasopressin is a substance that increases the blood level of clotting factor VIII, which is absent in haemophiliacs. Vasopressin has not been used to treat haemophiliacs, however, because among its side effects it is antidiuretic and raises blood pressure. The fact-finding committee reported that Cort's claims for reduced side-effects of the analogues were exaggerated in the patent application.

A second patent application, now pending, refers to two LHRH antagonists that Cort claimed to have synthesized; the committee could find no evidence to support this in laboratory records. These compounds were claimed to have a potential as birth-control drugs.

Cort's research at $\mathrm{Mt}$ Sinai was principally supported by a contract from Vega, and according to Mt Sinai "no significant use of public funds was involved". Cort did, however, receive a small amount of support under a general NIH grant to the chairman of Cort's department.

Mt Sinai officials are informing the Patent Office and the journals and coauthors of the misrepresetations. The papers that included the fabricated data were published in International Journal of Peptide and Protein Research and Advances in Physiological Sciences.

Stephen Budiansky 